\title{
THE USE OF WEB-BASED EXAM (WBE) TO OPTIMIZE STUDENTS' TESTING RESULT
}

\author{
Abdul Ngafif \\ English Education Program, Teacher Training and Education Faculty, Purworejo Muhammadiyah \\ University, Indonesia \\ E-mail: abdulngafif@gmail.com
}

\begin{abstract}
APA Citation: Ngafif, A. (2018). The use of web-based exam (WBE) to optimize students' testing result. English Review: Journal of English Education, 6(2), 41-50. doi: 10.25134/erjee.v6i2.1241.
\end{abstract}

Received: 11-02-2018

Accepted: 23-04-2018

Published: 01-06-2018

\begin{abstract}
This research was conducted based on the problems found during the mid and final test by using paper and pen test; those are the students tend to do cheating, the sleepy supervisors, the inconsistency of test time, and the risk of losing the answer sheet. Therefore, the goals of the research are; 1) to make an appropriate WBE testing system, 2) to know the cheating rate of the students, 3) to find out the effectiveness of the system, and 4) to inform the benefits that might be taken by the WBE testing system's users. By applying RnD research model, the researcher applies a concept called webbased exam system which uses three main tools to run the system (teacher's laptop as the server, WBE software, and access point to communicate the server and the user). The results indicated that the system reduces the students' cheating rate $100 \%$. Then, from the questionnaire given, the teacherstend to likeusing WBE testing system because they can monitor the whole process of the test from his own laptop and the result of the test will be analyzed and be saved automatically in his
\end{abstract} laptop. Moreover, it reduces time consumption and paper use.

Keywords: web-based exam, testing system, testing result, cheating, software

\section{INTRODUCTION}

The widespread use of e-exam as a tool to measure students' ability has risen to wide area of education. As Williams (2007) do to test pre-hospital students at Monash

University, it is found that the students found WBE experience to be very positive, preferred WBE to PBE and preferred to receive their test results automatically. Furthermore, Rutkowski, et al. (2007) developed a close-ended computer assisted exam which is go online in the form of web-based assessment and based on the questionnaire spread out to the students, it is found that the students have low difficulties to operate it, it has a direct result, and it is much better than PBE. In line with those, Chang and Ming (2012) had compared platform pattern of various web examination system and they use ASP.NET as the programming language with the background database is SQL Server version 2000. They use three basic layers in the system namely data layer (database), application layer (the software used), and user layer (the students).
The system provides a good condition for organizing all kinds of tests and also has a great reference value for other colleges and universities.

Web-based exam refers to a situation in which a student accesses questions and submits answers by a web browser and in which the exam results (partially or completely) determine the final grade for the subject (Sessink, et al., 2004). Meanwhile, Wang, et al. (2004) defines web-based exam as an exam works over internet and utilizes web browsers as its interface. It is not only provide online real-time tests and online construction of items, but also enable teachers to check answer sheets rapidly and record scores over the Internet.

Related to the use of web-based exam, Kuzmina (2010) points out that the benefits of using web-based exam are effective, efficient, safe, instant scoring, professional time, reducing time lag, greater availability, accuracy, standardization, control, and long- 
term cost saving. Rice (2003) states that the pros of using web-based test are it is effective for testing students' knowledge and attitudes, it is user-friendly, love to have direct result, less time to prepare, and the data are save and easy to be managed and to be analyzed. From the report of Prometric (2012), it is found that the benefits of using computer-based test are flexible, data-rich test result, enhanced security, consistency and reliability, availability of immediate scoring, streamlined logistic, multiple item types, and engaging navigation and presentation.

During the final test in English

Department of Muhammadiyah University of Purworejo in the academic year of 2015/2016, the researcher did an observation to the students and to the supervisors using an observation sheet. During the observation, he divided the observation based on two kinds of subject namely non skilled subject and skilled subject. The result shows that from six nonskilled subjects (Al Islam dan

Kemuhammadiyahan II, Pendidikan

Kewarganegaraan, Al Islam dan

Kemuhammadiyahan $I V$, Introduction to

Literature, CCU, and PPBI) followed by 810

students from semester II - VI, the total

students did cheating is $253(31 \%)$.

Meanwhile, from the eight skilled subjects

(Pre-intermediate grammar, English Varieties, Writing for Formal Communication, English Morphology, Modern English Grammar, Genre-based Reading, and Reading Comprehension V) followed by 978 students from semester II - VI, the total students did cheating is 163 students (17\%).

Besides grouping the students based on subjects, he also did grouping the students did cheating based on the type of the questions that is Multiple Choice Test, Essay Test, and Mixed Test (MC and Essay). The result shows that for MC test, there are 362 students among 780 students or $46.4 \%$. Then, for Essay Test, there are 69 students (12.9\%) among 534 students did cheating. Meanwhile, for Mixed Test question type, there are 179 students (40.7\%) among 440 students did cheating. For the supervisors of the test, from 16 supervisors there are 8 of them (50\%) did chatting outside of the class during the test, 6 supervisors
(37.5\%) did other job while waiting for the test, and only 2 supervisors (12.5\%) just focus on the test they supervised. From the findings above, it can be seen that the dominate students did cheating is on non-skilled subject and MC test type. Then, to overcome those problems, the writer develops a testing system called web-based exam.

The researcher is interested in developing that testing system because he sees that the test will be easier to be handled if there is a system which helps the teacher/lecturer in conducting the test included testing, analyzing, and saving the result. Meanwhile, it will be a transparent test if the students and the teacher are able to see the result of the test and they can discuss the test together. The other goal of the research is to reduce the weaknesses of the manual test such as cheating habit, the main role of the supervisors, the inconsistency of time, and the risk of losing/broken answer sheet. In developing the system, the researcher did collaboration with the lecturer, students, the stakeholders, and IT practitioner so that the system will be good. Then, after the system got ready, he needs three main tools to run the system those are the laptop which function as server, the web-based exam software, and the access point which functions to spread out the signal which is caught by the students' laptop to do the test. For the server, the teacher may transform his own laptop to be a server using wampserver software. The basic requirements of the laptop server are the clock should be higher than $1.5 \mathrm{GHz}$ and the RAM installed at least $4 \mathrm{~GB}$. After the server is ready, then the next is the web-based exam software. Here, the researcher with his team make software of computer based test and he named it with webbased exam 1.0. This software is easy to operate because it is windows-based and we have made the manual book so that the teachers can use it easily. The last tool is the access point which functions to communicate between the server and the users (the students' laptop).

In holding the test, the teacher just needs to plug the access point to his laptop and he needs to activate his laptop as server by clicking wampserver software. Then, he has to 
ENGLISH REVIEW: Journal of English Education Volume 6, Issue 2, June 2018

open the web-based exam software and set the test open so that it can be seen by the students. After that, he asks the students to do the test using any web browser installed in their own laptop and they must log in using username and password set before. When the students have already done the test, the result will be appeared both in the teacher and the students' laptop screen. By the time, the students can see which number answered correctly and incorrectly. By applying this system, the researcher can measure the students' real competence.

In doing the research, the researcher has two questions to be answered. Those are;

1) How is the development of WBE testing system?

2) Is WBE effective in overcoming the paper and pen problems?

\section{METHOD}

This research uses research and development (RnD) method developed by Richey (2007).This research is done in English Department of Muhammadiyah University of Purworejo. In running the research, the researcher takes three main steps namely exploring (research), developing (design and development), and evaluating (design research). In this report, the researcher discusses exploring stage or preliminary study as the first stage of the research. Meanwhile, the second stage is on progress. The subjects of the research are the students of English Education Program Purworejo

Muhammadiyah University in the academic year of 2016/2017. There are 99 students from 3 classes and 3lecturers (listening, grammar, and vocabulary) as the subject of the research which uses the researcher himself as the instrument and the researcher uses two supporting instruments namely observation
p-ISSN 2301-7554, e-ISSN 2541-3643 https://journal.uniku.ac.id/index.php/ERJEE

and questionnaire. The researcher takes the data for about 6 months since August 2016 till February 2017. The observation is chosen as a method to dig up problems arises during the test and the researcher uses the result of the early observation to plan up the solutions of the problems.

Qualitative analysis is a technique used to analyze the data. Here, the researcher analyzes the data from the observation and the questionnaire given to the students and the teachers of the three subjects. For additional information, the researcher also considers the validation result $f$ expert judgment from the IT and from the testing. For IT, the researcher asks the IT expert to do validation from the side of technology, system users, and the application in classroom. For the test, the researcher asks the expert of test to analyze the questions made by the teachers whether it has fulfilled the validity and the reliability of a good test.

\section{RESULT AND DISCUSSION \\ The way in developing web-based exam testing system}

Step 1. Observing

At the very beginning of the research, the researcher did an observation to get the early data. The observation was done during final exam in English Education Program of Purworejo Muhammadiyah Purworejo. In observing the students' activity in the test, the researcher observed them from a little hole in the door. The researcher categorized the students who do cheating if they see their friends' work, opening books, opening their phone cell, and asking the answer to their friends. Moreover, the researcher categorized the result of the observation into two category namely non-skilled subject and skilled subject.

Table 1. The observation's result of non-skilled subject

\begin{tabular}{lccc}
\hline \multicolumn{1}{c}{ Non-Skilled Subject } & $\begin{array}{c}\text { Total } \\
\text { Students }\end{array}$ & $\begin{array}{c}\text { Number of Cheating } \\
\text { Students }\end{array}$ & $\begin{array}{c}\text { Percentage of } \\
\text { cheating students }\end{array}$ \\
\hline AIK II & 99 & 63 & $63.64 \%$ \\
Pend. Kewarganegaraan & 99 & 22 & $22.22 \%$ \\
AIK IV & 138 & 61 & $44.20 \%$ \\
Intro to literature & 138 & 14 & $10.14 \%$ \\
Cross Cultural Understanding & 168 & 25 & $14.88 \%$ \\
PPBI & 168 & 68 & $40.48 \%$ \\
\hline
\end{tabular}


The use of web-based exam (WBE) to optimize students' testing result

Table 2. The observation's result of non-skilled subject

\begin{tabular}{lccc}
\hline \multicolumn{1}{c}{ Skilled Subject } & $\begin{array}{c}\text { Total } \\
\text { Students }\end{array}$ & $\begin{array}{c}\text { Number of Cheating } \\
\text { Students }\end{array}$ & $\begin{array}{c}\text { Percentage of } \\
\text { cheating students }\end{array}$ \\
\hline Pre-intermediate communicative grammar & 99 & 13 & $13.13 \%$ \\
English Varieties & 99 & 45 & $45.45 \%$ \\
Writing for formal comm. & 99 & 0 & $0.00 \%$ \\
Basic listening & 99 & 14 & $14.14 \%$ \\
English morphology & 138 & 16 & $11.59 \%$ \\
Modern Eng. Grammar & 138 & 23 & $16.67 \%$ \\
Genre-based reading & 138 & 20 & $14.49 \%$ \\
Reading V & 168 & 32 & $19.05 \%$ \\
\hline
\end{tabular}

The goal of observing is to get the early data so that the researcher knows the weaknesses of the testing system at the present. Here, the researcher divides the observation into two terms namely non-skilled subject which consists of 6 (six) subjects and skilled subject consists of 8 (eight) subjects. From the observation, the researcher found that the rate of the students' cheating is quite worse seen from the percentage Table 1 and 2 in which the highest cheating is on AIK II (63.64\%) and English varieties (45.45\%). From the observation, the researcher then got the idea to use WBE in order to reduce the cheating habits of the students.
Step 2. Drafting the system

From the observation, the researcher did early data. The next step is drafting the system by consulting it with IT expert to make a computerized testing system which can handle the problems found in conventional testing system. The main features of the system are login/registration, question bank, inserting media (picture and sound), time controller, auto correction, monitoring, and users. Figure 1 shows the draft of the system.

From a series of activities done in the research, the process of the test using webbased exam can be seen in Figure 2.

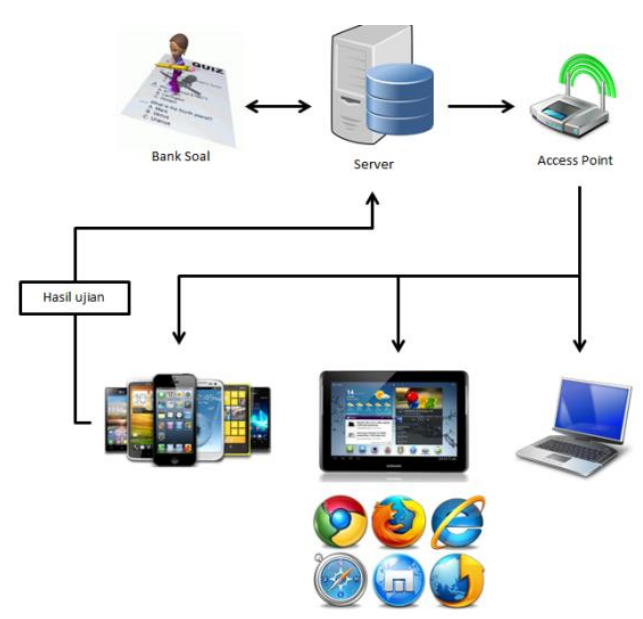

Figure1. Draft of WBE testing system

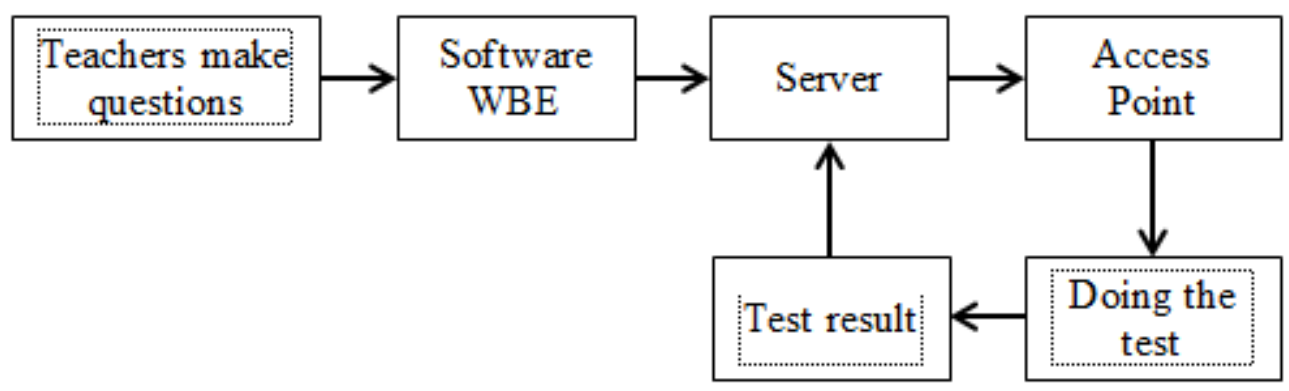

Figure 2. Diagram of WBE testing system 
ENGLISH REVIEW: Journal of English Education Volume 6, Issue 2, June 2018

The figure shows the process of test using web-based exam in which the tester upload the questions into server and then it is spread out through access point. Then, the students do the test using their own device. After the time finished, the score will be sent to the server automatically. To run the system, the writer uses software named web-based exam 1.0.
p-ISSN 2301-7554, e-ISSN 2541-3643 https://journal.uniku.ac.id/index.php/ERJEE
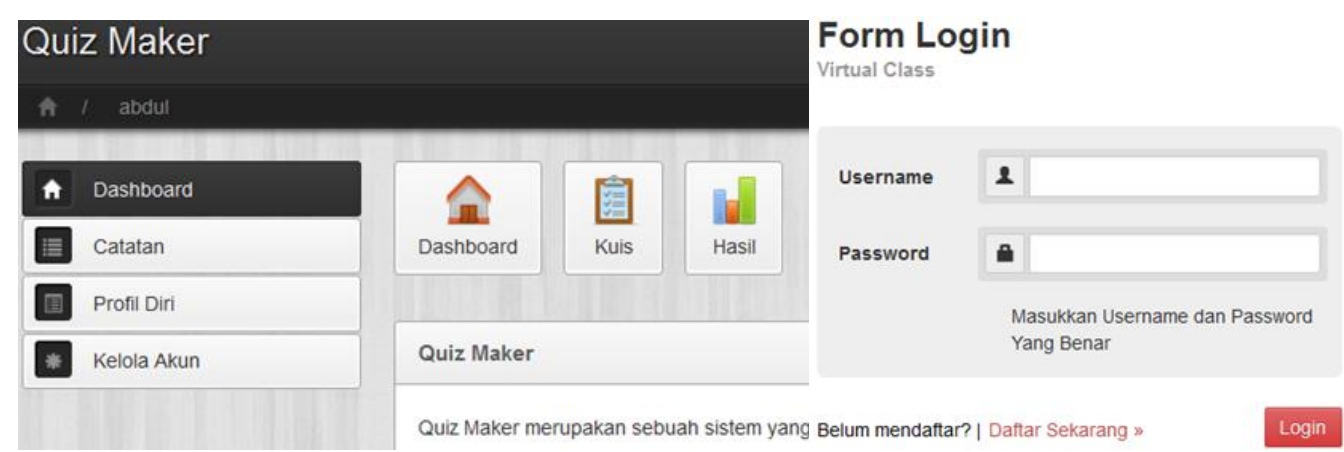

Figure 3. Main menu

Knowing that the rate of cheating habit is quite high, the researcher then drafts the system. By using AJAX language program and XAMPP (server software) combined with Access Point, the researcher makes the offline web-based exam. It consists of main menu, login, quiz form, and so on. The figure of the pages can be seen below.

\section{Form Login}

Virtual Class

Figure 4. Form login

Form Kuis

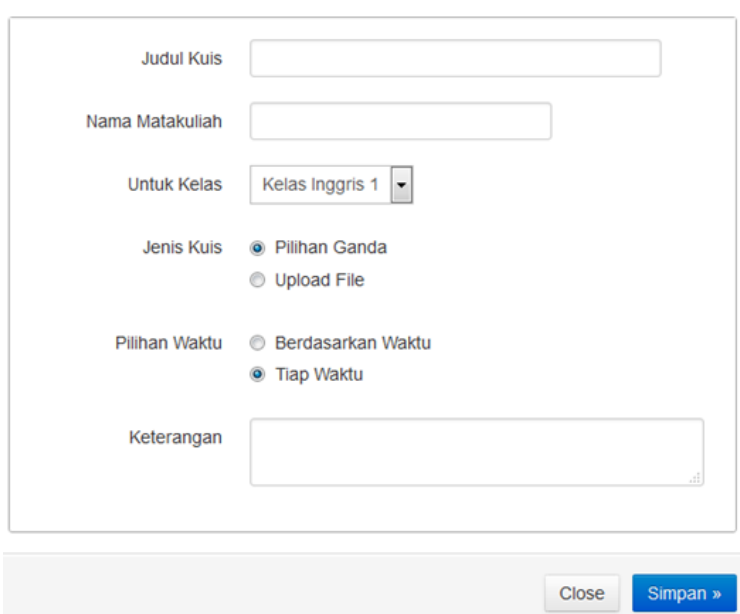

Figure 5. Making new quiz/test

When the early draft of the system was ready, the researcher then asks the expert of IT to check the system and the IT expert gives the following advices; 1) to smoothen the page to be more user friendly, 2) Database PHP MySQL is good, 3) the access point used should be changed to handle 30 students, and 4) the aspect of security should be paid attention more so that only administrator may handle the whole process of the test.

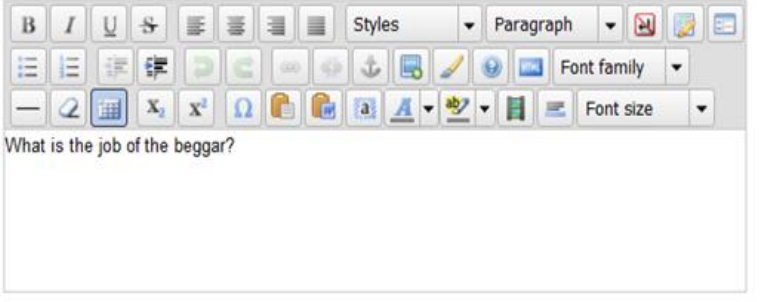

Figure 6. Page of question and answer

Step 3. Running the system

In running the system, the researcher did the following steps; 1) testing the system and evaluating it, 2) asking for expert to give comments and advices, 3) developing the system means the researcher overcomes the weaknesses of the system from evaluation and the advices of the expert, 4) re-testing the system which goals to know the system works well or not, 5) re-evaluating, and 6) asking for users to give assessment to the system. 
Holding the test and Evaluation I

Since all the system got ready, the researcher then held the test to know the system and later the researcher will have some evaluation on it. From the test, it is known that this system still has some weaknesses, including; 1) audio are not clear enough, 2) it has long transferring data (delay of one question and next question), and 3) sometimes the picture did not shown up. Then, the system cannot be applied when the laptop has low specification, so that the teacher (administrator) should use middle specification of laptop with minimum RAM 3 GB with processor which has clock speed 1.30 GB. This system requires no internet connection, so it will be no problem for them who have no internet connection in their school.

\section{Fixing the problems}

Knowing the weaknesses of the system, the researcher fixes it with the bug. The researcher then tests the system by himself to make sure that the weaknesses are already fixed up.

\section{Re-test the system and evaluation II}

In order to know the system is ready to be used, the researcher asks the lecturer and the students to have the test by using the system. From the test, it is known that the weaknesses as it is found in test I was already fixed.

\section{Students' cheating rate}

The subjects of the research are 99 students and 3 lecturers who take listening, grammar, and vocabulary subject. In test II, the researcher with the lecturer did observation to know the students' cheating rate, and from the observation, it is known that there is none of them did cheating because the lecturer set the questions to be answered just in a very limited time and when the time ends, the question will be closed automatically so that the students must answer the next questions. The result of observation can be seen in the table below.

Table 3. The observation's result of the research subject

\begin{tabular}{lccc}
\hline \multicolumn{1}{c}{ Subject } & $\begin{array}{c}\text { Total } \\
\text { students }\end{array}$ & $\begin{array}{c}\text { Number of Cheating } \\
\text { Students }\end{array}$ & $\begin{array}{c}\text { Percentage of } \\
\text { cheating students }\end{array}$ \\
\hline Listening for everyday communication & 99 & 0 & $0 \%$ \\
Intermediate communicative grammar & 99 & 0 & $0 \%$ \\
English vocabulary & 99 & 0 & $0 \%$ \\
\hline
\end{tabular}

Seeing from the observation at test II, there is no students who did cheating because their movements indicating to cheat are limited by the time. Furthermore, it is a fun for the researcher and the lecturers finding their students try to cheat by opening the dictionary or Google in their laptops but when they found what they are looking for, the time to answer the question in that number ends so that they have to answer the next question. Seeing the situation, the students just focus in answering the questions and afraid that the number of the question will close automatically if the time ends. That is a big progress.

\section{The effectiveness of the system in reducing the students' cheating habit}

In order to know the effectiveness of Web Based Exam testing system, the researcher did statistics computation by employing test of normality, test of homogeneity, and test of z. Before counting the statistics, the researcher determines the hypothesis that are the use of WBE testing system is ineffective to reduce the students' cheating habit (Ho) and the use of WBE testing system is effective to reduce the students' cheating habit (Ha). In counting test of normality, the researcher employs Chi Square test for independence formula, it is known that the data of the students are abnormal because the $\mathrm{x}^{2}$ value (listening, grammar, and vocabulary) is higher than the $\mathrm{x}^{2}$ table with degree of freedom 5\% (228.52, 25.16 , and $35.65>11.070$ ). To count the test of homogeneity, the researcher uses $\mathrm{F}$ formula and from the computation, it is known that the $F_{\text {value }}$ is lower than $F_{\text {table }}(1.137<1.822)$ means that the data are homogenous. Because the data have abnormal distribution so that the researcher uses Mann-Whitney U test to 
ENGLISH REVIEW: Journal of English Education Volume 6, Issue 2, June 2018

compute the effectiveness of the system and from the computation, it is known that $Z_{\text {value }}$ is higher than $Z_{\text {table }}(5.438>1.96)$ meaning that the use of Web Based Exam testing system is
p-ISSN 2301-7554, e-ISSN 2541-3643 https://journal.uniku.ac.id/index.php/ERJEE

Table 4. Statistics computation result

\begin{tabular}{lllcc}
\hline \multicolumn{1}{c}{ Computation } & Subjects & \multicolumn{1}{c}{ Statistics } & Results & Meaning \\
\hline Test of normality & Listening & Chi Square & $228.52>11.070$ & Abnormal \\
& Grammar & & $25.16>11.070$ & Abnormal \\
& Vocabulary & & $35.65>11.070$ & Abnormal \\
& & & $1.137<1.822$ & Homogenous \\
Test of homogeneity & & Ftest & $5.438>1.96$ & Effective \\
Test of hypothesis & & Mann Whitney U test & \\
\hline
\end{tabular}

To know whether the use of WBE testing system is effective or not, the researcher used two methods (observation and test result) in recognizing the effectiveness of the system in overcoming the students' cheating habit. From the observation, it can be known that there are no students did cheating because they have full concern to answer the questions in front of them. Furthermore, when they try to see their friends' work or when they want to see dictionary, they must be in rush due to the limitation of time and when they did it, they will miss the questions. Secondly, from the statistical computation, it shows that the $\mathrm{Z}_{\text {value }}$ is higher than $Z_{\text {table }}$ which indicates that the use of WBE testing system is effective to reduce effective to reduce the students' cheating habit (Ha is accepted). Below is the result of statistics computation in a brief. the students' cheating habit. From those two methods, it can be known that the use of WBE testing system is effective to reduce the students' cheating habit.

\section{Assessment from the users}

The researcher made questionnaire to know the effectiveness of the system. The researcher made two questionnaires for the lecturer and for the students. With the 110 students as its population, the questionnaire was given to 30 random students as respondents taken from 2 (two) different classes which is taught by the same lecturers. After the students answer all the statement in the questionnaire, the result of those can be seen in the chart below.

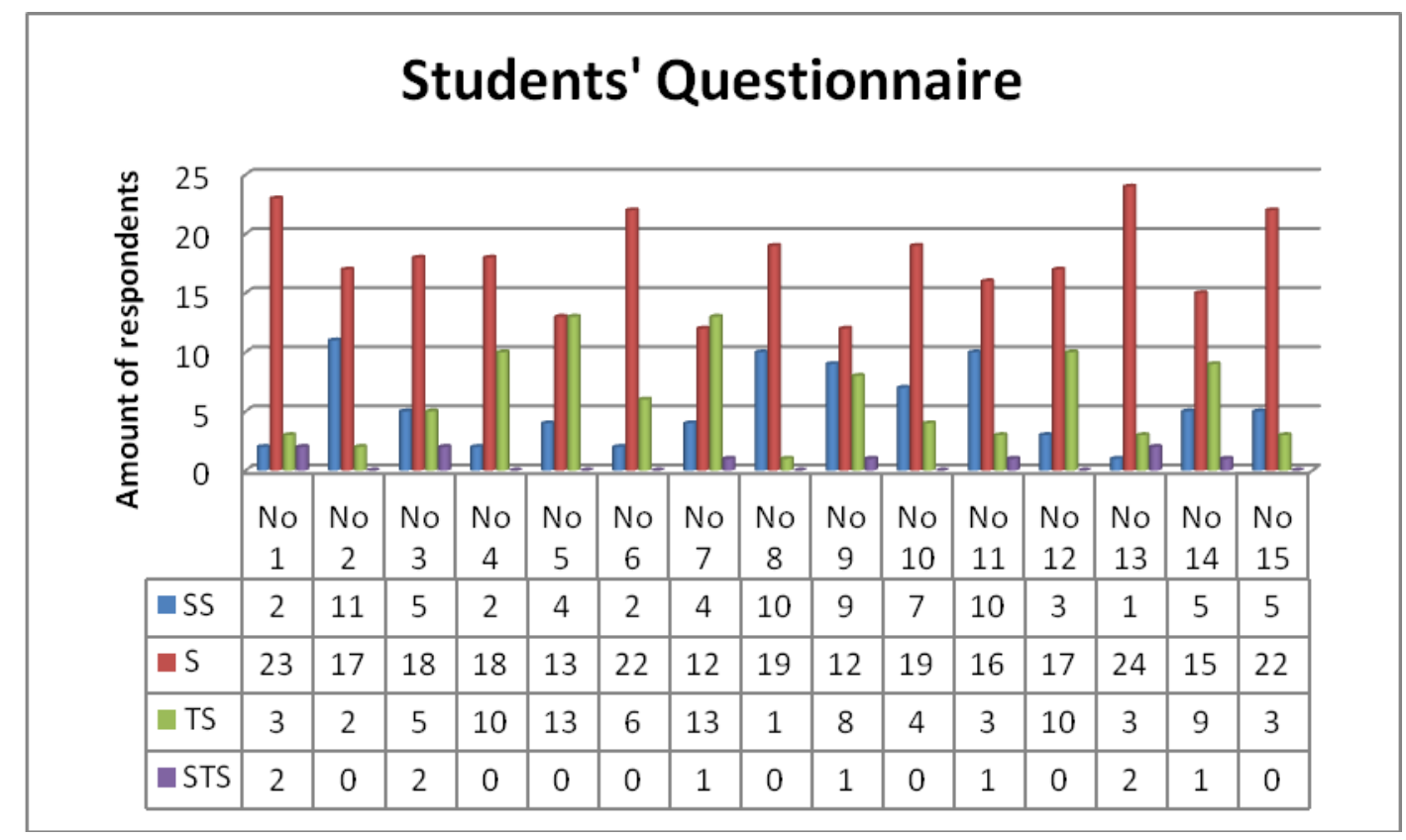

Figure 7. The result of students' questionnaire

From the result of questionnaire above, it can be known that; 1) most of the students prefer to have Web Based Exam than Paper

Based Exam, 2) they face no difficulties in 


\section{Abdul Ngafif}

The use of web-based exam (WBE) to optimize students' testing result

operating it due to it is windows-based, 3) they may see the result directly after the test ends, 4) they are hard to cheat because the questions are shown randomly, 5) they feel that it is more comfortable and focus in doing listening test because they use their own headset so that they pay more attention on it, and 6) some of them ignore the timer so that they got disappoint to have unfinished test.

The second questionnaire was given to the 3 (three) lecturers in English Education
Program as the subject of the research. The result of teacher's questionnaire shows that; 1) they like the auto correction feature because it helped them much in correcting the answer of the students, 2) this software is only appropriate for multiple choices test, not for essay, 3) they need to transfer the questions from Ms. Word to the system manually, it takes time, and 4) the system reduces the chance for students to cheat.

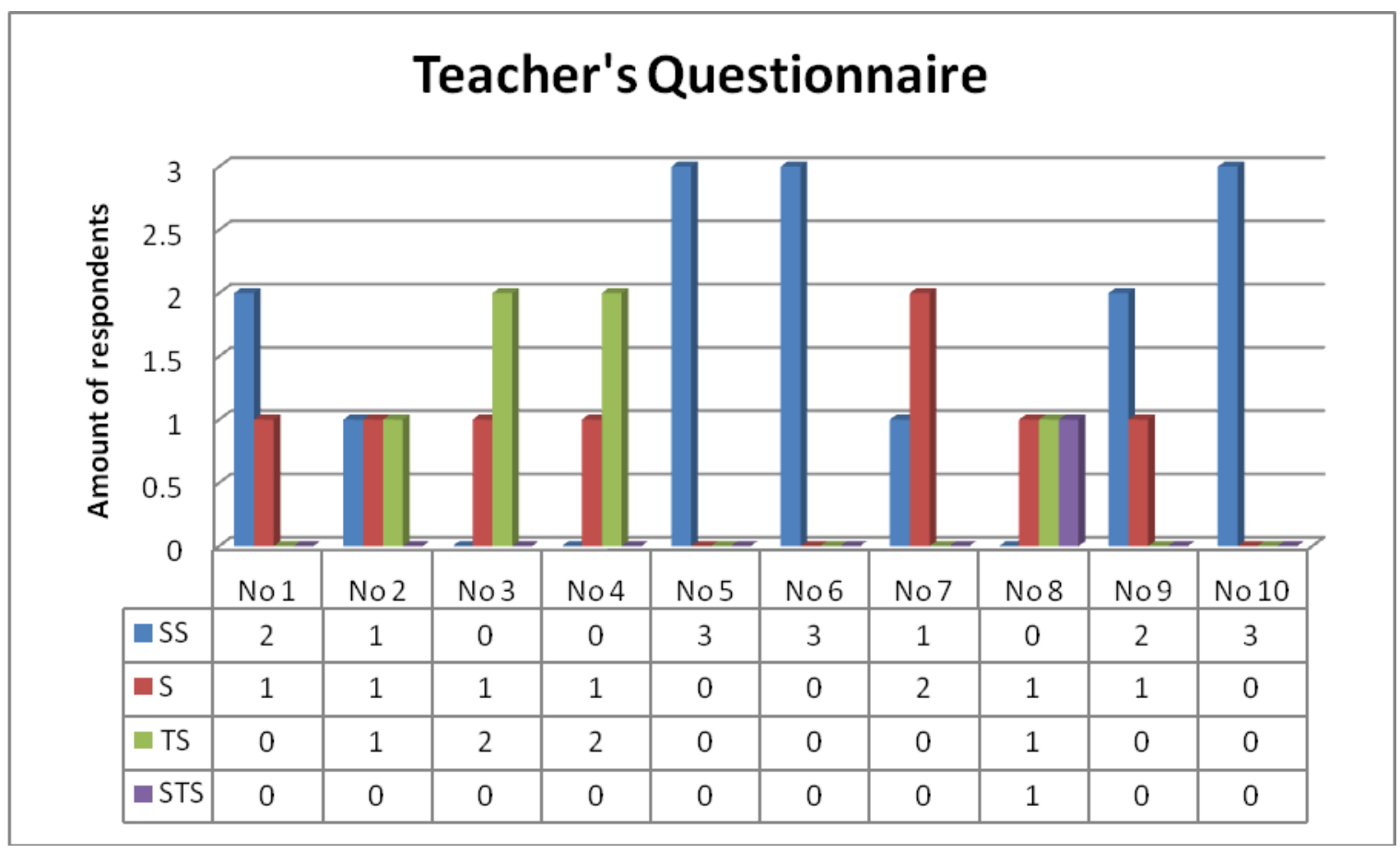

Figure 8. The result of teachers' questionnaire

\section{Benefit of the WBE testing system}

From the questionnaire, the benefits that can be taken by the teachers by applying this testing system, are; 1 ) no paper needed because all has been handed by the system, 2) the efficiently of time for doing and scoring the test, 3) scoring transparency, 4) the low cheating chance due to the questions appear in random, and 5) low cost of test due to no more paper needed. By using the same source, there is a significant influence of the system used toward teachers' testing model especially the teacher of the listening course. Those influences are; 1) it helps the teacher much in scoring and grading, 2) for the multiple choice test, this system appropriates much, and 3) it only appropriates to measure the students competence for knowledge and comprehension.

\section{CONCLUSION}

From a series of research findings and discussions, the researcher draws the following conclusions. First, the researcher succeeds in making the WBE testing system which is userfriendly, practical, and low cost. Moreover, the system can be applied in a middle specification of laptop (as server) and it requires no internet connection so that it will be no problem for the teacher and the students who have low fund to get internet connection. Second, from the observation and the statistical computation, it can be seen that the use of WBE testing system is effective to reduce the students' cheating habit. There is no 
ENGLISH REVIEW: Journal of English Education Volume 6, Issue 2, June 2018

students did cheating in the test and their movements to cheat are limited by the time so they will have no benefits to do cheating. Third, there are benefits that can be got from the usage of WBE testing system such as low chance to cheat, no paper needed, and efficiency of time. Moreover, by applying WBE testing system, the students' real competencies in taxonomy range 1 and 2 (remembering and understanding/comprehending) will be measured with great accuracy.

\section{REFERENCES}

Chang, L., \& Ming, X. G. (2012). Application research of WEB examination system based on college. Energy Procedia, 17, 528-533.

Kuzmina, I. P. (2010). Computer-based testing: Advantages and disadvantages. ВісникНаціональноготехнічногоуніверситету У краӥниКиївськийполітехнічнийінститут. Філософія. Психологія. Педагогіка, (1), 192-196.
p-ISSN 2301-7554, e-ISSN 2541-3643 https://journal.uniku.ac.id/index.php/ERJEE

Prometric. (2012). Converting to computerized testing: The benefits and best practices of computer-based testing. Industry report, $1^{\text {st }}$ quarter.

Rice, G. (2003). Designing online tests. Journal of Adventist Education April/May, 31.

Rutkowski, J., Moscinska, K., \& Jantos, P. (2007). Web-based assessment and examination systemfrom experiment to practice. In Proc. 10th IASTED Int. Conference on Computers and Advanced Technology in Education (CATE), Beijing-China (pp. 206-211).

Sessink, O., Beeftink, R., Tramper, J., \& Hartog, R. (2004). Securing web-based exams. Journal of Universal Computer Science, 10(2), 145-157.

Wang, T. H., Wang, K. H., Wang, W. L., Huang, S. C., \& Chen, S. Y. (2004). Web-based assessment and test analyses (WATA) system: Development and evaluation. Journal of Computer Assisted Learning, 20(1), 59-71.

Williams, B. (2007). Students' perceptions of prehospital web-based examinations. International Journal of Education and Development using ICT, $3(1)$. 
Abdul Ngafif

The use of web-based exam (WBE) to optimize students' testing result 